\title{
Meta-Analysis of the Effect of Technologies on Primary School
}

\author{
doi) https://doi.org/10.52105/temelegitim.3.2.3
}

Mustafa YESILYURT ${ }^{1}$

https://orcid.org/0000-0003-4108-7467

\begin{abstract}
:
The main purpose of this study is to show how much learning technologies increase the success in primary school with meta-analysis method. Advanced technologies such as virtual-augmented reality, animation-simulation, inverted classroom application, web-internet course applications, course and game teaching software, which are subject to experimental studies in computerized learning environments, have been included in this meta-analysis study, since they have features that can improve academic achievement. It is taken into account that having features such as; publication in a peer reviewed open-access magazines, the execution of the application by selecting the sample from the primary school in Turkey, listing the mean and standard deviation values and the number of sample group students for the final test, for the articles to be included in this research. It was concluded that advanced technology supported lesson applications in primary school have the ability to increase academic achievement at a very high level. The effect size found (md: 4.17239) is larger than the highest level value statements defined in the literature.
\end{abstract}

Keywords: Technological Course Material, Improving Classroom Teaching, Primary School.

To Cite This Article: Yesilyurt, M. (2021). Meta-Analysis of the Effect of Technologies on Primary School, Journal of Primary Education, 3(2), 2641. https://doi.org/10.52105/temelegitim.3.2.3

OPEN ACcess This articlel icensed under Creative Commons Attribution 4.0 International (CC BY 4.0) license and permanently free for everyone to read, download, copy, distribute and print.

\section{Introduction}

Having young and dynamic population ratios is the most important strength of societies. The existence of a young population is important for countries, however it is much more important that young people receive a good and quality education. The most important contribution of school processes to young people is to equip their learning environments with improved technological software for easy, fast and lasting teaching. A welfare society can be realized by the contribution of young people who are prepared for the unknowns of the future to scientific technological developments.

The economic development of societies, the allocation of necessary and sufficient budget to education, the development of countries, educational institutions, individuals and learning are interrelated. Quality equipment of learning environments ensures that what is learned is permanent. It triggers individuals raised with an improved education system to contribute to production and development.

There are several factors that trigger the academic success of individuals in learning environments. Constructivist or behavioral teaching programs, the dedication and being equipped of teachers, the technological materials of learning environments are some of the important factors that trigger the academic success of students. In order to the students to succeed academically, in the classroom and other settings, teachers have the opportunity to produce and use technological

\footnotetext{
${ }^{1}$ Assoc. Prof. Dr., Yildiz Technical University, myurt@yildiz.edu.tr
} 
materials, as well as to use improved technological materials (Fatimah \& Santiana, 2017; DarlingHammond, Flook, Cook-Harvey, Barron, \& Osher, 2020).

The institutions in which the teaching processes that start from pre-school and continue with the doctoral studies are carried out are important institutions that contribute to the development and welfare levels of societies. Using technological materials at primary school levels (including nursery class), where student development is matured, is thought to be as important as subsequent levels of instruction. It is known that developing technological material learning processes in primary school make it easier for students to acquire knowledge and skills, making the achievements permanent in long-term memory (Smith, Lowrey, Rowland, \& Frey, 2020, p. 70). In addition, technological material software triggers academic success.

Combining experimental applications with technological materials to increase the academic success of the student in primary school with meta-analysis is an important research topic that will determine the scientific relevance of technological materials software. After a systematic reporting, combining and reanalyzing quantitative data from independent articles is called meta-analysis (Ahn \& Kang, 2018; Acuna, Dossa, \& Baxter, 2020). In this meta-analytic method, it is important to combine the sample numbers of independent studies and increase the total number of students, while increasing the estimated power of the effect of the applied method on learning.

\section{The Problem of Research}

What is technological material (Fisher, Williamson, \& Guerra, 2020, p. 48; Urhan, Yüksel, \& Kocadere, 2017)? What technological course material will be included in this definition (Smith, Lowrey, Rowland, \& Frey, 2020, p. 68; Fisher, Williamson, \& Guerra, 2020, p. 50)? Do existing technologies and emerging technologies have an impact on course material creation (Oliveira, et al., 2019)? How does using technology in primary school contribute to students' learning (Domingo \& Garganté, 2016)? How do the learning environments using technological materials affect students' knowledge and skill achievements (Urhan, Yüksel, \& Kocadere, 2017)? What effect size would be created for experimental research with technological material when combined with Meta-analysis (Sung, Chang, \& Liu , 2016; Acuna, Dossa, \& Baxter, 2020)? What would the effect size founded by the meta-analysis method for experimental studies carried out at the primary school level be among those size levels defined in the literature (Sailer \& Homner, 2020; Pogrow, 2019)?

\section{Purpose of Research}

In this study, it was aimed to find the extent of impact, which is a measure of the contribution of technological material to academic success, by combining studies showing the impact of technologies on learning in primary school with meta-analysis.

\section{Importance of the Study}

This academic literature review study is important in that the academic success achieved through the use of various technological software materials in the learning environment shows the magnitude of the meta-analytic impact. Meta-analyses of independent studies based on student quantities determined are important for them to be examples of literature.

\section{Limitations of the Study}

The relevant criteria of the technological material studies carried out in primary school in Turkey in 2010-2011 and between 2014-2018 forms the limits of this study. In the data search, it is found that no articles published in Turkey in years 2012, 2013, 2019 and 2020 in accordance with the criteria of the study. This study is also limited to its own characteristics of meta-analysis, a method of literature review.

This meta-analysis study is limited to articles that meet the criteria of the study and are included in the meta-analysis. Therefore, this meta-analysis is also limited to the technological course materials in the included articles that were used to improve learning in Primary School. This meta-analysis study is limited to primary school class teachers' skills in using technology.

\section{Method}

In this study, applications using technological materials in primary school learning environment in Turkey were examined. In terms of its impact on academic success, quantitative data of experimental 
studies with control-group that examines the impact of using technological material are listed. In this study, Easy Meta Analysis software (mix 2.0 version) was selected to find the effect size of the data using technological materials consisting of independent studies. Mix 2.0 is an important and useful meta-analysis software that calculates the effect size based on the average values of the experimental and control groups.

\section{Effect Size Classification}

The effect size values based on the effect size classification calculated over the mean values of the groups in experimental studies are as listed below (Cohen, 1988, p. 198; Alegre, Moliner, Maroto, \& Lorenzo-Valentin, 2019; January \& Klingbeil, 2020);

- Has a small effect when md (effect size)=0.20.

- Has a moderate effect when md (effect size) $=0.50$.

- Has a wide effect when md (effect size)=0.80.

However, a more detailed classification can be made as follows (Dinçer, 2015, p. 102; Vincent \& Torres, 2015, p. 68; Cavalcanti, Campos, \& Araujo, 2012, p. 1269; Yüzlü \& Atay, 2020)

- $0.15<$ impact size value $<0.15$ is negligible,

- $0.15<$ impact size value $<0.40$ small level,

- $0.40<$ impact size value $<0.75$ medium level,

- $0.75<$ impact size value $<1.10$ large level,

- $1.10<$ impact size value $<1.45$ very large level,

- 1.45 < impact size value is excellent.

Alegre et al, concluded that the magnitude of the effect was very similar in general for qualitative and quantitative studies, in their literature study, and they used Cohen's d classification as a measure of magnitude for all the studies they worked on (Alegre, Moliner, Maroto, \& Lorenzo-Valentin, 2019).

January and Klingbeil, carried out a systematic review of measurements regarding the early reading curriculum with computer adaptive testing, and curriculum-based measurement (CMB) tools and in these studies, they showed that the early reading effect size findings and the reading success effect size findings obtained from meta-analysis have an effect size between medium and large classification according to Cohen's d classification (January \& Klingbeil, 2020). Vincent \& Torres used the effect size interpreted by Thalheimer \& Cook for Cohen's $d$ for group comparisons in their study (Vincent \& Torres, 2015). Yüzlü \& Atay conducted a study in which they applied the strategy of using mother tongue in foreign language teaching, and in these articles, they defined the effect size between the groups with Cohen d effect size calculator created by Thalheimer and Cook (Yüzlü \& Atay, 2020).

\section{Data Collection}

In the literature survey, keywords covering all technological material applications were used separately or together (Sterpetti, Costi, \& D'Ermo, 2020). Keywords such as animation, simulation, technology, technological materials, computers, information, software, artificial intelligence, intelligent lecture system, virtual reality, augmented reality, web, internet, Virtual Lab, Computer-Aided, computer-based, technology-supported, simulation-aided, animated instruction, lab simulations, webbased, internet-based, web-assisted lab, multi-media, multi-learning environment, inside out classroom, inside out classroom environment, course software, IT supported learning environment, computerized instruction, educational technology, instructional technology, success, academic success, effect of success, Primary School, nursery class have been used With the help of the listed keywords, 52 articles published between 2010-2020 in open-access peer-reviewed journals whose experimental samples were selected from primary school or nursery class in Turkey have been accessed. In these collected studies, the contribution of technological material applications to the academic success of the students was examined. 52 articles accessed have been reviewed, 33 data of the 16 articles which are controlgroup and have comparison data and provide other inclusion criteria have been recorded for metaanalysis. These 33 data are derived from articles published in 2010-2011 and between 2014-2018. Sterpetti, Costi, \& D'Ermo, in the meta-analysis of the articles on cancer, determined that there were 
many missing data in the published articles in order to reach meaningful results, and drew attention to the importance of data collection in meta-analysis studies (Sterpetti, Costi, \& D'Ermo, 2020).

The data collected from the articles conducted for primary school nursery class, first grade, second grade, third grade and fourth grade (according to the Turkish education system) students are listed according to grade levels. Unlike other countries, Primary School classroom teachers only educate students at the first, second, third, and fourth grade levels for four years (Official Gazette, 2012; Odabaşı, 2014). Non-compulsory nursery class education in primary school is carried out by pre-school teachers. The fifth grade classes in primary school are in the second tier of compulsory primary education in the Turkish education system. In the Turkish education system, fifth, sixth, seventh and eighth grades are provided at the secondary school level (Official Gazette, 2012; Odabaşı, 2014).

\section{Coding Process}

The number of students participating in the application, the average of the experiment group, the standard deviation of the experiment group, the average of the control group, the standard deviation of the control group, publication dates and author names were recorded for the 33 data that constitute the basis for the evaluation. In these studies, preliminary data were also examined in terms of validity and reliability.

\section{Validity Reliability}

For all articles accessed, it was determined that the application was made after the validity reliability study. For the data obtained from the articles that meet the criteria for inclusion in the Metaanalysis, validity has been found to be reliable. In addition, meta-analytic validity and reliability calculations were also performed (Wilson, Ritzhaupt, \& Cheng, 2020; Chen, Xie, Zou, \& Hwang, 2020; Garzón, Kinshuk, Baldiris, Gutiérrez, \& Pavón, 2020; Krott, Wild, \& Betsch, 2020; Ehrenbrusthof, Ryan, Grüneberg, \& Martin, 2018).

\section{Analysis of the Data}

The calculation of the differences between the averages of the control group studies in the recorded data was made by means of Mean Difference Effect Meta-analysis. MD common effect size (effect size) is converted from the data of the different studies included with meta-analysis.

Table 1. Effect Size Formulas and Conversion Formulas

\begin{tabular}{lll}
\hline Statistics & Effect size formulas (MD) & Conversion Descriptions \\
\hline \multirow{2}{*}{ Means } & $\mathrm{MD}=\mathrm{Me}-\mathrm{Mc}$ & $\mathrm{Me}=$ Mean of the experimental group \\
& $\mathrm{Mc}=$ Mean of the control group \\
\hline \multirow{2}{*}{ Variance } & $\mathrm{Sp}^{2}=\left[(\mathrm{Ne}-1) \mathrm{Se}^{2}+(\mathrm{Nc}-1) \mathrm{Sc}^{2}\right] \%[(\mathrm{Ne}+\mathrm{Nc}-2)$ & $\mathrm{Ne}=$ Number of individuals in experimental group \\
& & $\mathrm{Nc}=$ Number of individuals in control group \\
& $\mathrm{Se}^{2}=$ Variance of the experimental group \\
& $\mathrm{Sc}^{2}=$ Variance of the control group
\end{tabular}

The conversion formulas for MD effect size are shown in Table 1. Combining the data obtained from the accessible articles and saved with Meta analysis is provided from the MIX -Version 2.0 (made easy meta analysis) package program.

\section{Findings}

A meta-analysis of 33 data of 16 control-group articles, which meet the criteria determined by the researcher, and which measure the impact of technological material-supported applications in 4 years of Primary School in Turkey system was carried out. The Meta-analysis process is completed in two stages. The first phase process completed with a measure showing the effect of the learning method with 95\% confidence intervals (Cl) for each independent study. The second phase is completed by calculating an overall learning effect as the weighted average of summary statistics of independent articles. It should be noted that data from independent articles is not combined with a simple summation for meta-analysis. The data of articles that provide more information are more concentrated on in Meta-analytic combining. Numerical and graphic findings from the meta-analysis of 33 data sets were recorded. 
Journal of Primary Education, 2021, 3(2), 26-41

Table 2. Study Numbers, Authors, Publication Dates, and Primary School Grade Levels

\begin{tabular}{|c|c|c|c|}
\hline Study id & Writers & Date & levels \\
\hline Study 1 & (Yıldız, 2010, p. 47) & 2010 & 1 \\
\hline Study 2 & (Yıldız, 2010, p. 48) & 2010 & 1 \\
\hline Study 3 & (Gül \& Yeşilyurt, 2011a, p. 108) & $2011 a$ & 4 \\
\hline Study 4 & (Gül \& Yeşilyurt, 2011b, p. 37) & $2011 b$ & 4 \\
\hline Study 5 & (Orhan Karsak, 2014, p. 123) & 2014 & 1 \\
\hline Study 6 & (Orhan Karsak, 2014, p. 123) & 2014 & 1 \\
\hline Study 7 & (Orhan Karsak, 2014, p. 124) & 2014 & 1 \\
\hline Study 8 & (Orhan Karsak, 2014, p. 124) & 2014 & 1 \\
\hline Study 9 & (Orhan Karsak, 2014, p. 124) & 2014 & 1 \\
\hline Study 10 & (Orhan Karsak, 2014, p. 125) & 2014 & 1 \\
\hline Study 11 & (Orhan Karsak, 2014, p. 125) & 2014 & 1 \\
\hline Study 12 & (Orhan Karsak, 2014, p. 125) & 2014 & 1 \\
\hline Study 13 & (Orhan Karsak, Ada, \& Aşıcı, 2014, p. 284) & 2014 & 1 \\
\hline Study 14 & (Orhan Karsak, Ada, \& Aşıcı, 2014, p. 284) & 2014 & 1 \\
\hline Study 15 & (Orhan Karsak, Ada, \& Aşıcı, 2014, p. 285) & 2014 & 1 \\
\hline Study 16 & (Orhan Karsak, Ada, \& Aşıcı, 2014, p. 285) & 2014 & 1 \\
\hline Study 17 & (Orhan Karsak, Ada, \& Aşıcı, 2014, p. 286) & 2014 & 1 \\
\hline Study 18 & (Orhan Karsak, Ada, \& Aşıcı, 2014, p. 286) & 2014 & 1 \\
\hline Study 19 & (Gürol \& Yıldız, 2015, p. 13) & 2015 & 1 \\
\hline Study 20 & (Gürol \& Yıldız, 2015, p. 13) & 2015 & 1 \\
\hline Study 21 & (Gürol \& Yıldız, 2015, p. 14) & 2015 & 1 \\
\hline Study 22 & (Çeliköz \& Kol, 2016, p. 1809) & 2016 & Nursery Class \\
\hline Study 23 & (Çekirdekçi, Toptaş, \& Çekirdekçi, 2016, p. 89) & 2016 & 3 \\
\hline Study 24 & (Bütün Kar \& Elma, 2017, p. 537) & 2017 & 3 \\
\hline Study 25 & (Çoruk \& Çakır, 2017, p. 11) & 2017 & 4 \\
\hline Study 26 & (Çevik, Yılmaz, Göktaş, \& Gülcü, 2017, p. 54) & 2017 & Nursery Class \\
\hline Study 27 & (Akaydın \& Kaya, 2018, p. 4) & 2018 & 4 \\
\hline Study 28 & (Şahin \& Çakır, 2018, p. 82) & 2018 & 2 \\
\hline Study 29 & (Şahin \& Çakır, 2018, p. 82) & 2018 & 2 \\
\hline Study 30 & (Şahin \& Çakır, 2018, p. 82) & 2018 & 2 \\
\hline Study 31 & (Gökdaş \& Gürsoy, 2018, p. 166) & 2018 & 4 \\
\hline Study 32 & (Altıparmak \& Çiftçi, 2018, p. 242) & 2018 & 4 \\
\hline Study 33 & (Özerbaş \& Yalçınkaya, 2018, p. 10) & 2018 & 4 \\
\hline
\end{tabular}

Note: In Table 2, the articles included in the meta-analysis are cited.

When articles with more than one data are listed again in Table 2, they are listed together with their respective page numbers.

Table 3 lists the class level frequencies of the 33 datasets. According to this, meta analytic consolidation and impact size operations were performed for 19 data at first grade level, two each at 
nursery class and third grade level, 3 at second grade level, 7 at fourth grade level, and a total of 33 data.

Table 3. Frequency And Ratios Of Data Set By Class Level

\begin{tabular}{lll}
\hline Grade levels & Frequency & Percentage ratio \\
\hline Nursery class & 2 & $6 \%$ \\
\hline First grade & 19 & $58 \%$ \\
\hline Second grade & 3 & $9 \%$ \\
\hline Third grade & 2 & $6 \%$ \\
\hline Fourth grade & 7 & $21 \%$ \\
\hline Total & 33 & $100 \%$ \\
\hline
\end{tabular}

Table 4 lists which technological materials are used in primary school. According to this, computer-aided teaching, animation, digital material and lecturing video, multimedia, multimedia material, media-supported learning, augmented reality, computer-based teaching and similar technological materials were used. As is seen from this table, academic success is achieved by using technological materials in every subject and teaching every achievement in primary school.

Table 4. Technology And Subject Areas That Used İn Articles

\begin{tabular}{|c|c|c|c|}
\hline Levels & Date Authors & Technology & Workspace \\
\hline $\begin{array}{l}\text { Nursery } \\
\text { class }\end{array}$ & 2016 (Çeliköz \& Kol, 2016) & \multicolumn{2}{|c|}{ Computer Assisted Instruction Time and Space Concepts } \\
\hline $\begin{array}{l}\text { Nursery } \\
\text { class }\end{array}$ & $\begin{array}{c}2017 \text { (Çevik, Yılmaz, Göktaş, } \\
\text { Gülcü, 2017) }\end{array}$ & \&Augmented Reality & Learning English Vocabulary \\
\hline \multicolumn{2}{|c|}{ First grade 2010 (Yıldız, 2010) } & Multimedia & Reading Skills \\
\hline \multicolumn{2}{|c|}{ First grade 2014 (Orhan Karsak, 2014) } & \multicolumn{2}{|c|}{ Computer Assisted Instruction Reading and Writing } \\
\hline \multicolumn{2}{|c|}{$\begin{array}{l}\text { First grade } 2014 \text { (Orhan Karsak, Ada, } \\
\text { Aşıcı, 2014) }\end{array}$} & \&Computer Assisted Instructi & n Reading Writing \\
\hline \multicolumn{2}{|c|}{ First grade 2015 (Gürol \& Yıldız, 2015) } & Computer Based Education & Literacy Skills \\
\hline $\begin{array}{l}\text { Second } \\
\text { grade }\end{array}$ & 2018 (Şahin \& Çakır, 2018) & $\begin{array}{l}\text { Multimedia } \\
\text { Instruction }\end{array}$ & IsReading-Writing Skills \\
\hline $\begin{array}{l}\text { Third } \\
\text { grade }\end{array}$ & $\begin{array}{l}2016 \text { (Çekirdekçi, Toptaş, } \\
\text { Çekirdekçi, 2016) }\end{array}$ & \&Computer Assisted Instructi & n Geometry Course \\
\hline $\begin{array}{l}\text { Third } \\
\text { grade }\end{array}$ & 2017 (Bütün Kar \& Elma, 2017) & Media-Supported & Social Studies Course \\
\hline $\begin{array}{l}\text { Fourth } \\
\text { grade }\end{array}$ & 2011 (Gül \& Yeşilyurt, 2011a) & Computer Assisted Instructi & $\begin{array}{l}\text { n Science and Technology Lesson } \\
\text { (Breathing) }\end{array}$ \\
\hline $\begin{array}{l}\text { Fourth } \\
\text { grade }\end{array}$ & 2011 (Gül \& Yeşilyurt, 2011b) & Computer Assisted Instructi & $\begin{array}{l}\text { n Science and Technology Lesson } \\
\text { (Skeletal System) }\end{array}$ \\
\hline $\begin{array}{l}\text { Fourth } \\
\text { grade }\end{array}$ & 2017 (Çoruk \& Çakır, 2017) & Multimedia Material & Fractions Topic \\
\hline $\begin{array}{l}\text { Fourth } \\
\text { grade }\end{array}$ & 2018 (Akaydın \& Kaya, 2018) & Animation & $\begin{array}{l}\text { Social Studies Course Production to } \\
\text { Consumption Unit }\end{array}$ \\
\hline $\begin{array}{l}\text { Fourth } \\
\text { grade }\end{array}$ & 2018 (Gökdaş \& Gürsoy, 2018) & $\begin{array}{l}\text { Digital Material and Subj } \\
\text { Lecture Video }\end{array}$ & ctLet's Measure the Fluids \\
\hline
\end{tabular}


Journal of Primary Education, 2021, 3(2), 26-41

\begin{tabular}{lccccc}
\hline $\begin{array}{l}\text { Fourth } \\
\text { grade }\end{array}$ & 2018 (Altıparmak \& Çiftçi, 2018) $\begin{array}{c}\text { Computer } \\
\text { Mathematics }\end{array}$ & $\begin{array}{c}\text { Aided } \\
\text { Fractions }\end{array}$ & $\begin{array}{c}\text { RealisticFractions and } \\
\text { Operations }\end{array}$ & with \\
\hline $\begin{array}{l}\text { Fourth } \\
\text { grade }\end{array}$ & 2018 (Özerbaş \& & \&alçınkaya,Multimedia Material & Mathematics Course Angle and Angle \\
2018) & & & Measure & \\
\hline
\end{tabular}

Note: In Table 4, the articles included in the meta-analysis are cited.

Any articles showing that artificial intelligence technologies such as 'Intelligent lecture system' helps to improve learning in elementary school, not yet published in Turkey.

Easy Meta Analysis Mix 2.0 software program uses article number, author names, publication date, arithmetic mean and standard deviation of test and control groups, number of students in test and control groups for effect size calculation. In Table 5, the information of 33 data compiled from 16 articles, required for the calculation of impact magnitude, are listed by ordering as is mentioned.

Table 5. Study Number, Dates, Mean Value, Standard Deviation Value, Students' Number

\begin{tabular}{|c|c|c|c|}
\hline Study id & Writers & Date & levels \\
\hline Study 1 & (Yıldız, 2010, p. 47) & 2010 & 1 \\
\hline Study 2 & (Yıldız, 2010, p. 48) & 2010 & 1 \\
\hline Study 3 & (Gül \& Yeşilyurt, 2011a, p. 108) & $2011 a$ & 4 \\
\hline Study 4 & (Gül \& Yeşilyurt, 2011b, p. 37) & $2011 b$ & 4 \\
\hline Study 5 & (Orhan Karsak, 2014, p. 123) & 2014 & 1 \\
\hline Study 6 & (Orhan Karsak, 2014, p. 123) & 2014 & 1 \\
\hline Study 7 & (Orhan Karsak, 2014, p. 124) & 2014 & 1 \\
\hline Study 8 & (Orhan Karsak, 2014, p. 124) & 2014 & 1 \\
\hline Study 9 & (Orhan Karsak, 2014, p. 124) & 2014 & 1 \\
\hline Study 10 & (Orhan Karsak, 2014, p. 125) & 2014 & 1 \\
\hline Study 11 & (Orhan Karsak, 2014, p. 125) & 2014 & 1 \\
\hline Study 12 & (Orhan Karsak, 2014, p. 125) & 2014 & 1 \\
\hline Study 13 & (Orhan Karsak, Ada, \& Aşıcı, 2014, p. 284) & 2014 & 1 \\
\hline Study 14 & (Orhan Karsak, Ada, \& Aşıcı, 2014, p. 284) & 2014 & 1 \\
\hline Study 15 & (Orhan Karsak, Ada, \& Aşıcı, 2014, p. 285) & 2014 & 1 \\
\hline Study 16 & (Orhan Karsak, Ada, \& Aşıcı, 2014, p. 285) & 2014 & 1 \\
\hline Study 17 & (Orhan Karsak, Ada, \& Aşıcı, 2014, p. 286) & 2014 & 1 \\
\hline Study 18 & (Orhan Karsak, Ada, \& Aşıcı, 2014, p. 286) & 2014 & 1 \\
\hline Study 19 & (Gürol \& Yıldız, 2015, p. 13) & 2015 & 1 \\
\hline Study 20 & (Gürol \& Yıldız, 2015, p. 13) & 2015 & 1 \\
\hline Study 21 & (Gürol \& Yıldız, 2015, p. 14) & 2015 & 1 \\
\hline Study 22 & (Çeliköz \& Kol, 2016, p. 1809) & 2016 & Nursery Class \\
\hline Study 23 & (Çekirdekçi, Toptaş, \& Çekirdekçi, 2016, p. 89) & 2016 & 3 \\
\hline Study 24 & (Bütün Kar \& Elma, 2017, p. 537) & 2017 & 3 \\
\hline Study 25 & (Çoruk \& Çakır, 2017, p. 11) & 2017 & 4 \\
\hline Study 26 & (Çevik, Yılmaz, Göktaş, \& Gülcü, 2017, p. 54) & 2017 & Nursery Class \\
\hline Study 27 & (Akaydın \& Kaya, 2018, p. 4) & 2018 & 4 \\
\hline Study 28 & (Şahin \& Çakır, 2018, p. 82) & 2018 & 2 \\
\hline
\end{tabular}


Journal of Primary Education, 2021, 3(2), 26-41

\begin{tabular}{llll}
\hline Study 29 & (Şahin \& Çakır, 2018, p. 82) & 2018 & 2 \\
\hline Study 30 & (Şahin \& Çakır, 2018, p. 82) & 2018 & 2 \\
\hline Study 31 & (Gökdaş \& Gürsoy, 2018, p. 166) & 2018 & 4 \\
\hline Study 32 & (Altıparmak \& Çiftçi, 2018, p. 242) & 2018 & 4 \\
\hline Study 33 & (Özerbaş \& Yalçınkaya, 2018, p. 10) & 2018 & 4 \\
\hline
\end{tabular}

Note: In Table 5, the articles included in the meta-analysis are cited.

Required calculations have been made for the 33 data uploaded to the Easy Meta Analysis Mix 2.0 software program system. At the end of related calculations, a value of 251,92811 for Q, a value of 2,80584 for $\mathrm{H}$, a value of $87,298 \%$ for 12 , a value of 5,02568 for $\mathrm{t} 2$ are calculated and shown in Table 6. These values indicate that the relevant data is heterogeneous.

Table 6. Heterogeneity Statistics

\begin{tabular}{llll}
\hline Deviation & Estimate & Q-df & p \\
\hline $\mathrm{Q}$ & 251,92811 & 217,92811 & 0 \\
\hline Inconsistency & Estimate & ci- & $\mathrm{ci+}$ \\
\hline $\mathrm{H}$ & 2,80584 & 2,44083 & 3,22544 \\
\hline $\mathrm{I}^{2}$ & $87,298 \%$ & $83,215 \%$ & $90,388 \%$ \\
\hline & & & \\
\hline Variance & Estimate & $\mathrm{ci}-$ & $\mathrm{ci}+$ \\
\hline $\mathrm{t}^{2}$ & 5,02538 & 3,62507 & 6,87583 \\
\hline
\end{tabular}

The fact that the value of 12 is $75 \%$ and greater is considered an important indicator for heterogeneity (Owen, Cooper, Quinn, Lees, \& Sutton, 2018; Harper, Carling, \& Kiely, 2019, p. 1927; Huedo-Medina, Sa'nchez-Meca, Marı́n-Martı́nez, \& Botella, 2006; Bowden, Tierney, Copas, \& Burdett, 2011, p. 4). The values shown in Table 6 in this meta-analysis study remain unchanged according to the calculation for the constant effect and random effect.

The selectivity funnel diagram is shown in Figure 1 by drawing a funnel chart. This funnel chart drawing points to the potential for publication bias due to the formation of asymmetry. The potential for publication bias can be eliminated by papers not published in peer-reviewed journals, such as those presented in academic forums. These papers are unlikely to be included in the analysis as they are not always achievable, and publication bias for similar reasons is a limitation in the nature of meta-analysis (Mavridis \& Salanti, 2014; van Aert, Wicherts, \& van Assen, 2019). 


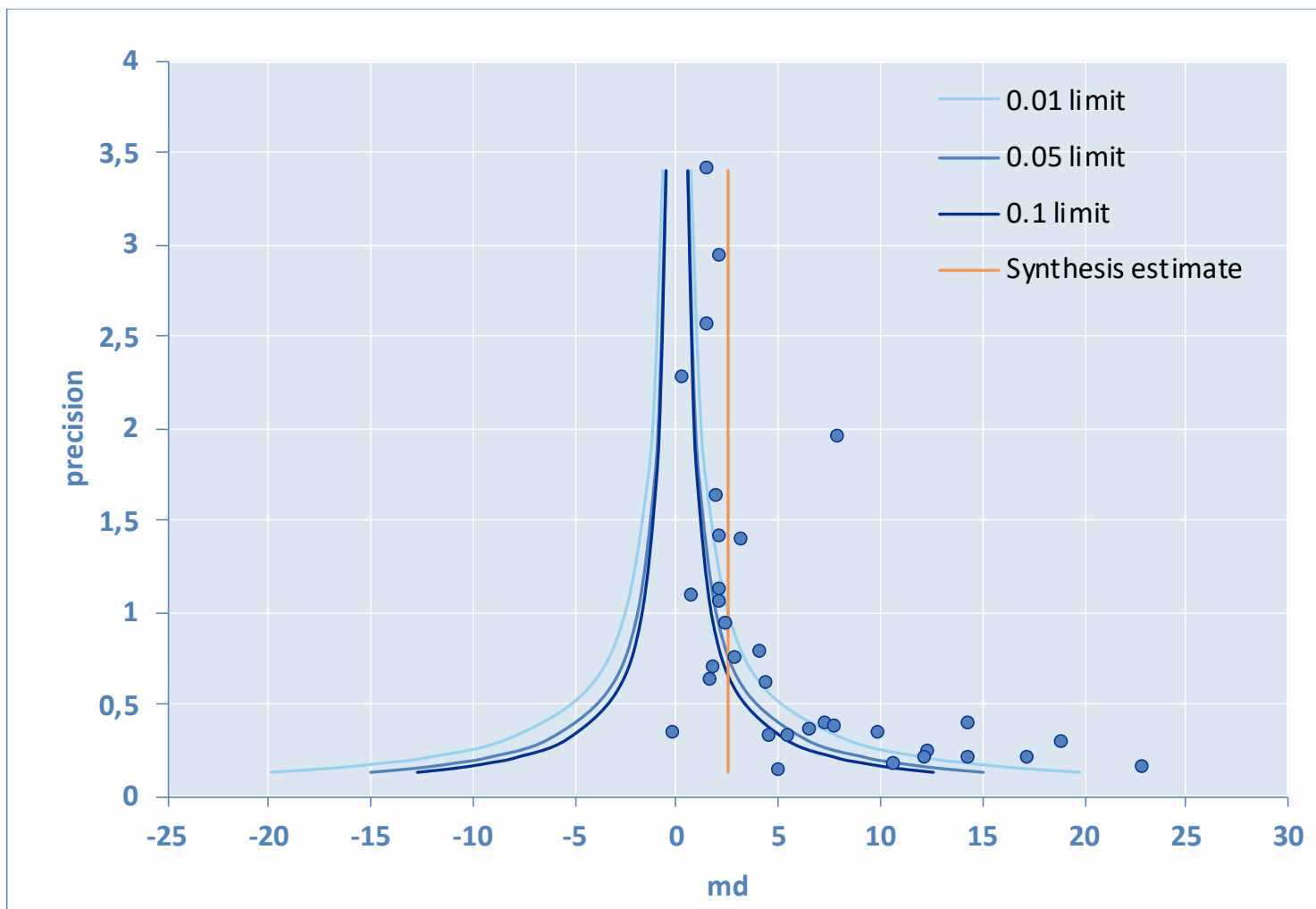

(The synthesis estimate is shown the orange vertical line)

Figure 1. Selectivity funnel plot

Note: All figures must be printed colored

In this meta-analysis, only the articles that their samples were selected from Turkey and published in Turkey were reported. Therefore, the formation of asymmetry in Figure 1 (Debray, Moons, \& Riley, 2018) refers to the reporting of articles whose publication language is Turkish and published in Turkey.

The synthesis estimate is shown in Orange in Figure 1, and a significant portion of the values representing 33 data are excluded from the drawing representing the limit values of the funnel diagram. Thus, it is understood from the funnel chart drawing in Figure 1 that the data being analyzed is heterogeneous. Meta-analysis of this heterogeneous data was performed using random effect model.

The effect size calculated using the random effect model via Easy Meta Analysis Mix 2.0 software program has a value of 4,17239 for MD and is listed in Table 7 along with other detailed calculation values. It is shown in Table 7 that the effect size can take values between 3,1567 and 5,18808 .

Table 7. Dissemination Bias

\begin{tabular}{llll} 
Method & md & ci- & ci+ \\
\hline Original & 4,17239 & 3,1567 & 5,18808 \\
\hline Trim And Fill Correction & 1,81617 & 1,55136 & 2,08098 \\
\hline * The bias analysis results should be treated as exploratory & &
\end{tabular}

The id numbers, subject numbers, contributions to meta analytic effect size of the independent articles and the smallest-largest value of these contributions in the $95 \%$ confidence interval, the $Z$ value, the $p$ significance value and the weight values are listed in column positions and other calculated total synthesis details Table 8 are listed in the last row. The calculated total effect size of the contribution of technological material to learning in primary school is given in md 4,17239 in the last 
Journal of Primary Education, 2021, 3(2), 26-41

row of the third column of the table. The last column of Table 8 contains the calculated weight values for each data.

Table 8. Synthesis Details

\begin{tabular}{|c|c|c|c|c|c|c|c|}
\hline Study id & $\mathrm{N}$ & md & ci- & $\mathrm{ci+}$ & $z$ & $p$ & $w$ \\
\hline Study 1 & 73 & 2,59 & 0,46401 & 4,71599 & 2,38774 & 0,01695 & $4,33 \%$ \\
\hline Study 2 & 73 & 2,15 & 0,28154 & 4,01846 & 2,25529 & 0,02411 & $4,53 \%$ \\
\hline Study 3 & 56 & 2,18 & 0,77454 & 3,58546 & 3,0401 & 0,00237 & $4,85 \%$ \\
\hline Study 4 & 55 & 3,35 & 1,93577 & 4,76423 & 4,64273 & $<0.00001$ & $4,84 \%$ \\
\hline Study 5 & 64 & 0,44 & $-0,42796$ & 1,30796 & 0,99357 & 0,32043 & $5,14 \%$ \\
\hline Study 6 & 64 & 1,53 & 0,95404 & 2,10596 & 5,20648 & $<0.00001$ & $5,25 \%$ \\
\hline Study 7 & 64 & 1,54 & 0,77285 & 2,30715 & 3,93448 & 0,00008 & $5,19 \%$ \\
\hline Study 8 & 64 & 1,97 & $-0,89353$ & 4,83353 & 1,34838 & 0,17754 & $3,75 \%$ \\
\hline Study 9 & 64 & 2,12 & 0,90878 & 3,33122 & 3,43051 & 0,0006 & $4,97 \%$ \\
\hline Study 10 & 64 & 7,44 & 2,41371 & 12,46629 & 2,90117 & 0,00372 & $2,31 \%$ \\
\hline Study 11 & 50 & 6,62 & 1,0249 & 12,2151 & 2,31899 & 0,0204 & $2,04 \%$ \\
\hline Study 12 & 14 & 10,79 & $-1,53591$ & 23,11591 & 1,71574 & 0,08621 & $0,60 \%$ \\
\hline Study 13 & 20 & 12,39 & 3,69024 & 21,08976 & 2,79134 & 0,00525 & $1,09 \%$ \\
\hline Study 14 & 44 & 5,5 & $-0,62186$ & 11,62186 & 1,76087 & 0,07826 & $1,82 \%$ \\
\hline Study 15 & 44 & 4,73 & $-1,47848$ & 10,93848 & 1,49322 & 0,13538 & $1,78 \%$ \\
\hline Study 16 & 20 & 12,24 & 2,54244 & 21,93756 & 2,47381 & 0,01337 & $0,91 \%$ \\
\hline Study 17 & 10 & 5,08 & $-10,0059$ & 20,1659 & 0,66 & 0,50926 & $0,42 \%$ \\
\hline Study 18 & 54 & 7,81 & 2,36239 & 13,25761 & 2,80992 & 0,00496 & $2,11 \%$ \\
\hline Study 19 & 58 & 14,4 & 9,20684 & 19,59316 & 5,43474 & $<0.00001$ & $2,23 \%$ \\
\hline Study 20 & 58 & 0 & $-5,8853$ & 5,8853 & 0 & 1 & $1,91 \%$ \\
\hline Study 21 & 58 & 17,28 & 6,83772 & 27,72228 & 3,24337 & 0,00118 & $0,80 \%$ \\
\hline Study 22 & 60 & 7,97 & 6,9581 & 8,9819 & 15,43722 & $<0.00001$ & $5,07 \%$ \\
\hline Study 23 & 73 & 2,29 & 1,62095 & 2,95905 & 6,70845 & $<0.00001$ & $5,22 \%$ \\
\hline Study 24 & 31 & 2,98 & 0,31865 & 5,64135 & 2,19463 & 0,02819 & $3,91 \%$ \\
\hline Study 25 & 62 & 4,16 & 1,62563 & 6,69437 & 3,21715 & 0,00129 & $4,01 \%$ \\
\hline Study 26 & 31 & 4,5 & 1,25838 & 7,74162 & 2,72082 & 0,00651 & $3,46 \%$ \\
\hline Study 27 & 33 & 1,77 & $-1,38059$ & 4,92059 & 1,10111 & 0,27085 & $3,53 \%$ \\
\hline Study 28 & 30 & 9,93 & 3,98551 & 15,87449 & 3,27403 & 0,00106 & $1,89 \%$ \\
\hline Study 29 & 30 & 2,2 & 0,42644 & 3,97356 & 2,43122 & 0,01505 & $4,60 \%$ \\
\hline Study 30 & 30 & 0,87 & $-0,95772$ & 2,69772 & 0,93295 & 0,35085 & $4,56 \%$ \\
\hline Study 31 & 56 & 14,36 & 4,20655 & 24,51345 & 2,77197 & 0,00557 & $0,84 \%$ \\
\hline Study 32 & 82 & 19,03 & 11,99734 & 26,06266 & 5,30356 & $<0.00001$ & $1,50 \%$ \\
\hline \multirow[t]{3}{*}{ Study 33} & 35 & 22,9 & 9,85271 & 35,94729 & 3,44004 & 0,00058 & $0,54 \%$ \\
\hline & $\mathrm{N}$ & md & ci- & $\mathrm{ci+}$ & z & p & w \\
\hline & 1624 & 4,17239 & 3,1567 & 5,18808 & 8,05138 & $<0.00001$ & $100 \%$ \\
\hline
\end{tabular}


The synthesis diagram chart (synthesis forest plot), calculated by Meta-analysis and generated from the information listed in Table 8, is shown in Figure 2 (Rücker \& Schwarzer, 2020). In the synthesis diagram chart, created from the findings of 33 data in the synthesis details table, the squares represent the probability ratios of independent articles, the horizontal lines that cut these squares show $95 \% \mathrm{Cl}$ confidence intervals. The field of the squares reflects the weight that each article contributes to the meta-analysis.

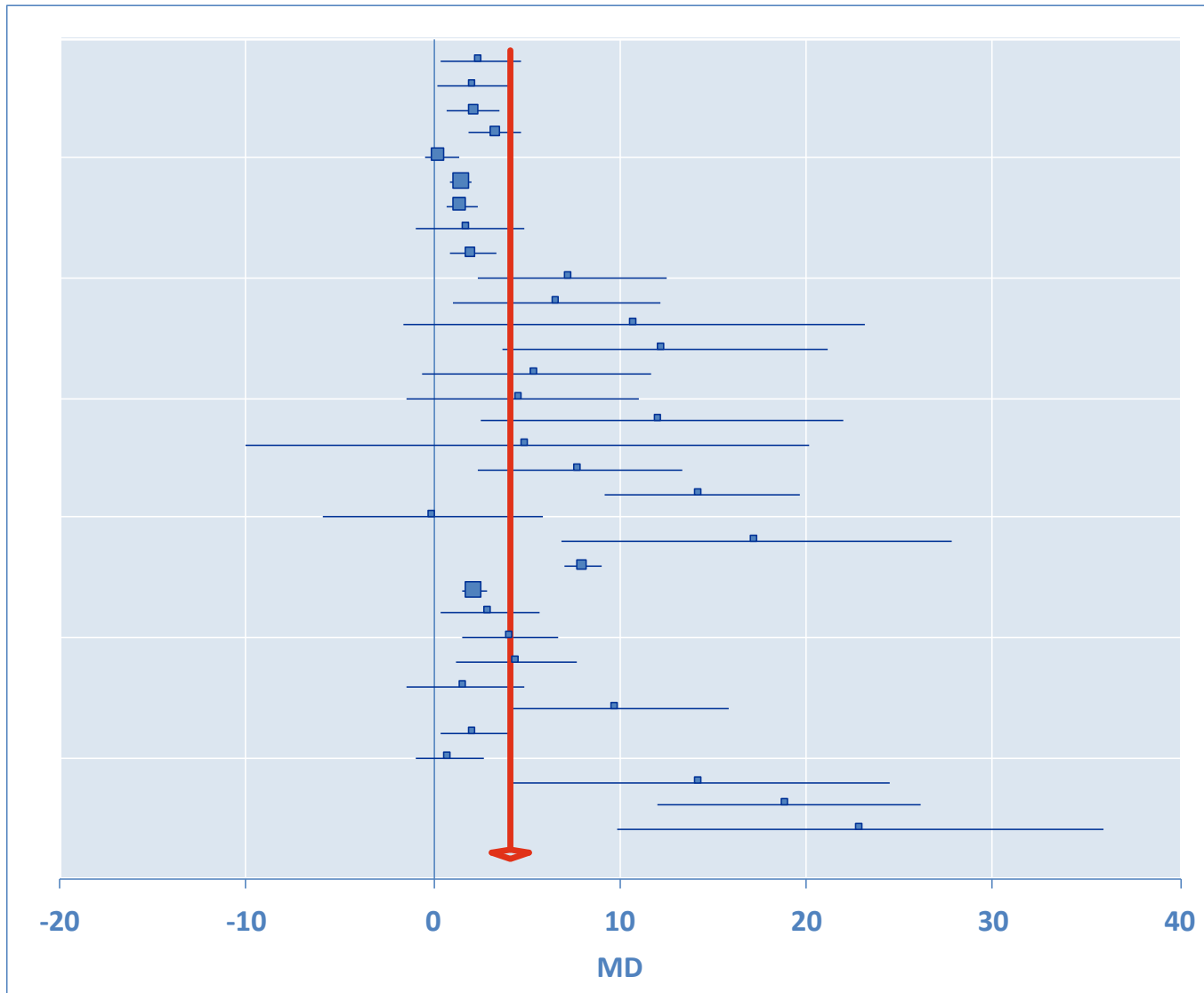

(The diamond below the red vertical line represents the MD effect size)

Figure 2. Synthesis forest plot

Note: All figures must be printed colored

In Figure 2, the diamond below the red vertical line represents the MD effect size. In this chart, center of the diamond that shows MD the effect size represents the effect of technological material on learning (md: 4,17239). There is one square in the graph for each of the works listed in Table 8. In Figure 2, The Vertical order of the squares and the rows in Table 8 overlap. The lengths of horizontal lines that cross frames represent $95 \%$ of the confidence interval between ci - and ci+ for each data, as listed in Table 8.

\section{Results}

What is technological material?

In this meta-analytic literature survey, all possible materials with technological content that can be used to improve academic achievement in learning environments were evaluated as technological course materials (Wilson, Ritzhaupt, \& Cheng, 2020; Saini \& Salim Al-Mamri, 2019). Wilson et al, examined technological course materials that affect learning environments and pre-service teacher training, which are the product of existing technologies and emerging technologies (Wilson, Ritzhaupt, \& Cheng, 2020). 
What technological course material will be included in this definition? Do existing technologies and emerging technologies have an impact on course material creation?

The technological materials used in the learning environment are listed in Table 4 as augmented reality (Oranç \& Küntay, 2019; Garzón, Kinshuk, Baldiris, Gutiérrez, \& Pavón, 2020), computer-based education, multimedia-supported material, computer-aided instruction, multimedia material, computeraided realistic math material, animation, digital material and lecturing video. As is seen here, emerging technologies such as animation and augmented reality are also being used as materials in learning environments and contribute to academic success. Garzón et al, conducted a meta-analysis study on course material with augmented reality content (Garzón, Kinshuk, Baldiris, Gutiérrez, \& Pavón, 2020). In addition, there are course material studies with virtual reality simulation content in the literature (O'Connor, et al., 2020).

\section{How does using technology in primary school contribute to students' learning?}

It is understood from the experimental applications of the meta-analytic papers (Çoruk \& Çakır, 2017; Çevik, Yılmaz, Göktaş, \& Gülcü, 2017; Altıparmak \& Çiftçi, 2018; Akaydın \& Kaya, 2018) that using technological materials is significantly effective in teaching the predicted achievements of the courses conducted in primary school (Lai \& Bower, 2019; Fidan \& Tuncel, 2019; Şahin \& Yılmaz, 2020). Lai and Bower, defined the impact of technologies on learning and how much interest learning technologies receive in their work on evaluating learning technologies (Lai \& Bower, 2019). In addition, two studies conducted by Fidan \& Tuncel and Şahin \& Yılmaz in Turkey show that augmented reality technology is effective in the science achievements of Secondary School seventh grade students (Fidan \& Tuncel, 2019; Şahin \& Yılmaz, 2020).

How do the learning environments using technological materials affect students' knowledge and skill achievements?

According to the findings of each articles included in the Meta-analysis (Şahin \& Çakır, 2018; Akaydın \& Kaya, 2018), the relevant experimental research with technological material were found contributing to academic success on significant levels (Shen \& Ho, 2020; Chen, Xie, Zou, \& Hwang, 2020). Shen \& Ho, analyzed articles on technological material and noted that the results of teaching and learning were enriched at the higher education level with course material developed with technology (Shen \& Ho, 2020). Chen et al, examined articles applying artificial intelligence technologies to education and listed the most commonly used artificial intelligence technologies as machine learning, intelligent tutoring system and artificial neural networks (Chen, Xie, Zou, \& Hwang, 2020).

What effect size would be created for experimental research with technological material when combined with Meta-analysis?

The MD: 4,17239 value for the calculated meta analytic effect size for a total of 33 datasets of 16 articles that meet the inclusion criteria in the literature review shows that technological materialsupported teaching contributes far more to academic success than the methods and practices carried out in control groups (Rakes, et al., 2020; Gegenfurtner \& Ebner, 2019; Marion-Martins \& Pinho, 2020; Scherer \& Teo, 2019). The common view of the 16 papers reviewed is that the use of technological materials at primary school level facilitates learning and increases academic achievement. MarionMartins \& Pinho conducted a meta-analysis study that showed that simulation technology was effective in training nursing students (Marion-Martins \& Pinho, 2020). Gegenfurtner \& Ebner have defined that webinars are effective for higher education and vocational education students through their meta-analysis work (Gegenfurtner \& Ebner, 2019). Although it is statistically significant, Rakes et al, concluded that their evidence was insufficient to make claims about the overall effectiveness of technology in a student's mathematics achievement, due to their very small effect sizes in their metaanalysis (Rakes, et al., 2020).

What would the effect size founded by the meta-analysis method for experimental studies carried out at the primary school level be among those size levels defined in the literature?

In the literature, the highest effect size classification in meta-analysis studies has a value of $\mathrm{md}>$ 1.45 and the perfect level definition for this effect size value has been made (Dinçer, 2015, p. 102; Vincent \& Torres, 2015, p. 68; Cavalcanti, Campos, \& Araujo, 2012, p. 1269). In this study, md: 4,17239 value was reached for meta analytic effect size, well above the level defined in the literature, in order to find out the extent of the impact of computerized technological material on academic success in 
primary school. However, a high-level value for effect size may not only be the usual result of metaanalysis. The asymmetry that appears to be the publication bias in Figure 1, which actually indicates the reporting of articles published in Turkey, created a larger impact value than expected in this metaanalysis study (Debray, Moons, \& Riley, 2018; van Aert, Wicherts, \& van Assen, 2019). Thus, all the questions of the study were answered and the purpose of the study was realized.

\section{Recommendations}

Our children who are tomorrow's elders and will achieve social development and experience a welfare society, should have the opportunity and possibility to recognize technology to grow academic achievement in primary school. For this purpose, classroom teachers should be trained in educational faculties and their learning environments should be equipped with emerging technologies. Teaching technologies and material design courses in classroom teaching programs must be conducted in the technological equipped learning environments. In a word, classroom teachers should be familiar with technology. Classroom teacher candidates should be encouraged to learn and use technology. Thus, the competence of the classroom teacher candidates to produce and use technological materials should be improved. The final recommendation of this study is that how technological material learning environments affect attitudes and motivation in primary school should also be investigated.

\section{References}

(Note: The articles listed below with (*) an asterisk sign which also included in the meta-analysis are cited in Tables 2, 4 and 5).

Acuna, S. A., Dossa, F., \& Baxter, N. (2020). Meta-analysis of noninferiority and equivalence trials: ignoring trial design leads to differing and possibly misleading conclusions. Journal of Clinical Epidemiology, 127(2020), 134-141. Retrieved from https://www.sciencedirect.com/science/article/pii/S0895435619303087

Ahn, E., \& Kang, H. (2018). Introduction to systematic review and meta-analysis. Korean Journal of Anesthesiology, 71(2), 103-112. Retrieved from https://www.ncbi.nlm.nih.gov/pmc/articles/PMC5903119/pdf/kjae-201871-2-103.pdf

*Akaydın, B. B., \& Kaya, S. (2018). The Effect of 5E Model with and without Animation on Students' Achievement and Attitude in Social Studies. Kastamonu Education Journal, 26(1), 171-179. Retrieved from https://dergipark.org.tr/tr/download/article-file/400101

Alegre, F., Moliner, L., Maroto, A., \& Lorenzo-Valentin, G. (2019). Peer tutoring and mathematics in secondary education: literature review, effect sizes, moderators, and implications for practice. Heliyon, 5(9), e02491. Retrieved from https://www.sciencedirect.com/science/article/pii/S2405844019361511

*Altıparmak, K., \& Çiftçi, B. (2018). An Experimental Study on the Effectiveness of Computer Aided Realistic Mathematics Education. Necatibey Faculty of Education, Electronic Journal of Science and Mathematics Education, 12(2), 228-253. Retrieved from https://dergipark.org.tr/tr/download/article-file/616184

Bowden, J., Tierney, J. F., Copas, A. J., \& Burdett, S. (2011). Quantifying, displaying and accounting for heterogeneity in the meta-analysis of RCTs using standard and generalised $\mathrm{Q}$ statistics. BMC Medical Research Methodology, 11(41). $\quad$ Retrieved from https://bmcmedresmethodol.biomedcentral.com/track/pdf/10.1186/1471-2288-11-41

*Bütün Kar, E., \& Elma, C. (2017). The Effects of Media-Supported Education on Academic Success and Permanence of Learning in Social Studies Course. Mersin University Journal of the Faculty of Education, 13(2), 531-549. Retrieved from https://dergipark.org.tr/tr/download/article-file/387979

Cavalcanti, P., Campos, T., \& Araujo, J. (2012). Actigraphic Analysis of the Sleep-Wake Cycle and Physical Activity Level in Patients with Stroke: Implications for Clinical Practice. Chronobiology International, 29(9), 12671272. Retrieved from https://www.tandfonline.com/doi/full/10.3109/07420528.2012.719960

Chen, X., Xie, H., Zou, D., \& Hwang, G.-J. (2020). Application and theory gaps during the rise of Artificial Intelligence in Education. Computers and Education: Artificial Intelligence, 1(2020), 100002. Retrieved from https://www.sciencedirect.com/science/article/pii/S2666920X20300023

Cohen, J. (1988). Statistical Power Analysis for the Behavioral Sciences (Second Edition). New York: LAWRENCE ERLBAUM ASSOCIATES, PUBLISHERS. Retrieved July 08, 2020, from http://www.utstat.toronto.edu/ brunner/oldclass/378f16/readings/CohenPower.pdf

*Çekirdekçi, S., Toptaş, V., \& Çekirdekçi, N. (2016). The Effect of Computer Assisted Instruction According to Bruner's Cognitive Development Principles on 3rd Grade Geometry Course Achievement and Permanency of Learned. Cumhuriyet International Journal of Education-CIJE, 5(USOS Özel Sayı), 82-96. Retrieved from https://dergipark.org.tr/en/download/article-file/314358 
*Çeliköz, N., \& Kol, S. (2016). Gaining The Effect of Time and Space Concepts to Six Year-Old Children in Computer Assisted Instruction. Kastamonu Education Journal, 24(4), 1803-1820. Retrieved from https://dergipark.org.tr/tr/download/article-file/323481

*Çevik, G., Yılmaz, R. M., Göktaş, Y., \& Gülcü, A. (2017). English Vocabulary Learning with Augmented Reality in Preschool. Journal of Instructional Technologies and Teacher Education, 6(2), 50-57. Retrieved from https://dergipark.org.tr/en/download/article-file/347160

*Çoruk, H., \& Çakır, R. (2017). The Effect of Multimedia Usage on Academic Achievement and Anxiety of Primary School Students. Turkish Journal of Computer and Mathematics Education, 8(1), 1-27. Retrieved from https://dergipark.org.tr/tr/download/article-file/269421

Darling-Hammond, L., Flook, L., Cook-Harvey, C., Barron, B., \& Osher, D. (2020). Implications for educational practice of the science of learning and development. Applied Developmental Science, 24(2), 97-140. Retrieved

https://www.tandfonline.com/doi/pdf/10.1080/10888691.2018.1537791?needAccess=true from

Debray, T. P., Moons, K. G., \& Riley, R. D. (2018). Detecting small-study effects and funnel plot asymmetry in metaanalysis of survival data: A comparison of new and existing tests. Res Syn Meth, 2018(9), 41-50. Retrieved from https://onlinelibrary.wiley.com/doi/epdf/10.1002/jrsm.1266

Dinçer, S. (2015). Effects of Computer-Assisted Learning on Students' Achievements in Turkey: A Meta-Analysis. Journal of Turkish Science Education, 12(1), 99-118. Retrieved from https://www.tused.org/index.php/tused/article/view/414/352

Domingo, M. G., \& Garganté, A. B. (2016). Exploring the use of educational technology in primary education: Teachers' perception of mobile technology learning impacts and applications' use in the classroom. Computers in Human Behavior, 56, 21-28. Retrieved from https://www.sciencedirect.com/science/article/pii/S0747563215302387

Ehrenbrusthof, K., Ryan, C. G., Grüneberg, C., \& Martin, D. J. (2018). A systematic review and meta-analysis of the reliability and validity of sensorimotor measurement instruments in people with chronic low back pain. Musculoskeletal Science and Practice, , 35(2018), 73-83. Retrieved from https://www.sciencedirect.com/science/article/pii/S2468781218300535\#!

Fatimah, A. S., \& Santiana, S. (2017). Teaching in 21st Century: Students-Teachers' Perceptions of Technology Use in the Classroom. Script Journal: Journal of Linguistics and English Teaching, 2(2), 125-135. Retrieved from https://jurnal.fkip-uwgm.ac.id/index.php/Script/article/view/132/pdf

Fidan, M., \& Tuncel, M. (2019). Integrating augmented reality into problem based learning: The effects on learning achievement and attitude in physics education. Computers \& Education, 142(2019), 103635. Retrieved from https://www.sciencedirect.com/science/article/pii/S0360131519301885

Fisher, K. W., Williamson, H., \& Guerra, N. (2020). Technology and Social Inclusion: Technology Training and Usage by Youth with IDD in the National Longitudinal Transition Study of 2012. Inclusion, 8(1), 43-57. Retrieved from https://experts.illinois.edu/en/publications/technology-and-social-inclusion-technology-training-andusage-by-

Garzón, J., Kinshuk, Baldiris, S., Gutiérrez, J., \& Pavón, J. (2020). How do pedagogical approaches affect the impact of augmented reality on education? A meta-analysis and research synthesis. Educational Research Review, 31(Kasım 2020), 100334. Retrieved from https://www.sciencedirect.com/science/article/pii/S1747938X19303525

Gegenfurtner, A., \& Ebner, C. (2019). Webinars in higher education and professional training: A meta-analysis and systematic review of randomized controlled trials. Educational Research Review, 28(2019), 100293. Retrieved from https://www.sciencedirect.com/science/article/pii/S1747938X1830561X

*Gökdaş, I., \& Gürsoy, S. (2018). The Effect of Flipped Classroom Model on Academic Achievement and Motivation in Maths Lesson at Primary Schools. Mediterranean Journal of Educational Research, 12(26), 159-174. Retrieved from https://mjer.penpublishing.net/makale indir/714

*Gül, Ş., \& Yeşilyurt, S. (2011a). The Effect of Computer Assisted Instruction Based Constructivist Learning Approach on Students' Attitudes and Achievements. Necatibey Faculty of Education Electronic Journal of Science and Mathematics Education, 5(1), 94-115. Retrieved from https://dergipark.org.tr/tr/download/article-file/39814

*Gül, Ş., \& Yeşilyurt, S. (2011b). The Effect of Computer Assisted Instruction on Fourth Grade Primary Students' Achievements and Attitudes towards Science and Technology Lesson. E-International Journal of Educational Research, 2(1), 30-43. Retrieved from http://www.e-ijer.com/en/download/article-file/89718 
*Gürol, A., \& Yıldız, E. (2015). The Effects of Computer Based Education on Initial Literacy Skills of First Grade Students. International Journal of Field Education, 1(1), 1-18. Retrieved from https://dergipark.org.tr/tr/download/article-file/90116

Harper, D. J., Carling, C., \& Kiely, J. (2019). High-Intensity Acceleration and Deceleration Demands in Elite Team Sports Competitive Match Play: A Systematic Review and Meta-Analysis of Observational Studies. Sports Medicine(49), 1923-1947. Retrieved from https://link.springer.com/content/pdf/10.1007/s40279-01901170-1.pdf

Huedo-Medina, T. B., Sa'nchez-Meca, J., Marı́n-Martı́nez, F., \& Botella, J. (2006). Assessing Heterogeneity in Meta-Analysis: Q Statistic or I 2 Index? Psychological Methods, 11(2), 193-206. Retrieved from https://pdfs.semanticscholar.org/6620/cb1331499385f3e8daad453734560f930257.pdf

January, S.-A. A., \& Klingbeil, D. A. (2020). Universal screening in grades K-2: A systematic review and metaanalysis of early reading curriculum-based measures. Journal of School Psychology, 82(2020), 103-122. Retrieved from https://www.sciencedirect.com/science/article/pii/S0022440520300509

Krott, N. L., Wild, M., \& Betsch, M. (2020). Meta-analysis of the validity and reliability of rasterstereographic measurements of spinal posture. European Spine Journal, 29, 2392-2401. Retrieved from https://link.springer.com/article/10.1007/s00586-020-06402-x

Lai, J. W., \& Bower, M. (2019). How is the use of technology in education evaluated? A systematic review. Computers \& Education, 133(2019), 27-42. Retrieved from https://www.sciencedirect.com/science/article/pii/S0360131519300120

Marion-Martins, A. D., \& Pinho, D. L. (2020). Interprofessional simulation effects for healthcare students: A systematic review and meta-analysis.,. Nurse Education Today, 94(2020), 104568. Retrieved from https://www.sciencedirect.com/science/article/pii/S0260691720314180

Mavridis, D., \& Salanti, G. (2014). Exploring and accounting for publication bias in mental health: a brief overview of methods. Evidence-Based Mental Health, 17(1), 1-15. Retrieved from http://dx.doi.org/10.1136/eb-2013101700

O'Connor, M., Stowe, J., Potocnik, J., Giannotti, N., Murphy, S., \& Rainford, L. (2020). 3D virtual reality simulation in radiography education: The students' experience. Radiography. Retrieved from https://www.radiographyonline.com/article/S1078-8174(20)30141-3/fulltext

Odabaşı, B. (2014). Thoughts Upon New Regulation Change $(4+4+4)$ in Turkish Education System. Cukurova University Faculty of Education Journal, 43(2), 103-124. Retrieved from https://dergipark.org.tr/tr/download/article-file/46537

Official Gazette. (2012, April 11). Law on Amendments to the Law on Primary Education and Education and Some Laws. Official Gazette. Retrieved from https://www.resmigazete.gov.tr/eskiler/2012/04/20120411-8.htm

Oliveira, A., Behnagh, R. F., Ni, L., Mohsinah, A. A., Burgess, K. J., \& Guo, L. (2019). Emerging technologies as pedagogical tools for teaching and learning science: A literature review. Human Behavior \& Emerging Technologies, 1(1), 149-160. Retrieved from https://onlinelibrary.wiley.com/doi/10.1002/hbe2.141

Oranç, C., \& Küntay, A. C. (2019). Learning from the real and the virtual worlds: Educational use of augmented reality in early childhood. International Journal of Child-Computer Interaction, 21(September 2019), $104-111$. Retrieved from https://www.sciencedirect.com/science/article/pii/S221286891830028X

*Orhan Karsak, H. G. (2014). The Effect of Computer Assisted Instruction on Elementary Reading and Writing Achievement. Journal of Theoretical Educational Science, 7(1), 114-134. Retrieved from https://dergipark.org.tr/tr/download/article-file/304243

*Orhan Karsak, H. G., Ada, S., \& Aşıcı, M. (2014). By The Status of Pre-School Education and the Effort by Parents the Effect of Computer Assisted Instruction to First Reading Writing Success. NWSA-Education Sciences, 1C0618, 9(3), 276-292. Retrieved from https://dergipark.org.tr/tr/download/article-file/185362

Owen, R. K., Cooper, N. J., Quinn, T. J., Lees, R., \& Sutton, A. J. (2018). Network meta-analysis of diagnostic test accuracy studies identifies and ranks the optimal diagnostic tests and thresholds for health care policy and decision-making. Journal of Clinical Epidemiology, 99, 64-74. Retrieved from https://www.jclinepi.com/article/S0895-4356(17)30941-1/fulltext

*Özerbaş, M. A., \& Yalçınkaya, M. (2018). The Effect of the Use of Multimedia on Academic Success and Motivation. Journal of Research in Education and Society/JRES, 5(2), 1-21. Retrieved from https://dergipark.org.tr/tr/download/article-file/612431

Pogrow, S. (2019). How Effect Size (Practical Significance) Misleads Clinical Practice: The Case for Switching to Practical Benefit to Assess Applied Research Findings. The Amerıcan Statıstıcıan, 73(Sup1), 223-234. 
Retrieved

from https://www.tandfonline.com/doi/epub/10.1080/00031305.2018.1549101?needaccess=true

Rakes, C. R., Ronau, R. N., Bush, S. B., Driskell, S. O., Niess, M. L., \& Pugalee, D. K. (2020). Mathematics achievement and orientation: A systematic review and meta-analysis of education technology, 31. Educational Research Review, 31(2020), 100337. Retrieved from https://www.sciencedirect.com/science/article/pii/S1747938X19301800

Rücker, G., \& Schwarzer, G. (2020). Beyond the forest plot: The drapery plot. Research Synthesis Methods, 2020(Special Issue), 1-7. Retrieved from https://onlinelibrary.wiley.com/doi/full/10.1002/jrsm.1410

Sailer, M., \& Homner , L. (2020). The Gamification of Learning: a Meta-analysis. 32, 77-112 (2020). Educational Psychology Review, 32, 77-112. Retrieved from https://link.springer.com/content/pdf/10.1007/s10648019-09498-w.pdf

Saini, D. K., \& Salim Al-Mamri, M. R. (2019). Investigation of Technological Tools used in Education System in Oman. Social Sciences \& Humanities Open, $1(1$ ), 100003. Retrieved from https://www.sciencedirect.com/science/article/pii/S2590291119300038

Scherer, R., \& Teo, T. (2019). Unpacking teachers' intentions to integrate technology: A meta-analysis. Educational Research Review, 27(2019), 90-109. Retrieved from https://www.sciencedirect.com/science/article/pii/S1747938X18303622

Shen, C.-w., \& Ho, J.-t. (2020). Technology-enhanced learning in higher education: A bibliometric analysis with latent semantic approach. Computers in Human Behavior, 104(2020), 106177. Retrieved from https://www.sciencedirect.com/science/article/pii/S0747563219303899

Smith, S. J., Lowrey, K. A., Rowland, A. L., \& Frey, B. (2020). Effective Technology Supported Writing Strategies for Learners with Disabilities. Inclusion, 8(1), 58-73. Retrieved from https://aquila.usm.edu/fac_pubs/17143/

Sterpetti, A. V., Costi, U., \& D'Ermo, G. (2020). National statistics about resection of the primary tumor in asymptomatic patients with Stage IV colorectal cancer and unresectable metastases. Need for improvement in data collection. A systematic review with meta-analysis. Surgical Oncology, 33(2020), 11-18. Retrieved from https://www.sciencedirect.com/science/article/pii/S0960740419303147\#!

Sung, Y.-T., Chang, K.-E., \& Liu , T.-C. (2016). The effects of integrating mobile devices with teaching and learning on students' learning performance: A meta-analysis and research synthesis. Computers \& Education, 94(2016), 252-275. Retrieved from https://www.sciencedirect.com/science/article/pii/S0360131515300804

Şahin, D., \& Yılmaz, R. M. (2020). The effect of Augmented Reality Technology on middle school students' achievements and attitudes towards science education. Computers \& Education, 144(2020), 103710. Retrieved from https://www.sciencedirect.com/science/article/pii/S0360131519302635

*Şahin, F., \& Çakır, R. (2018). Effects of Multimedia Materials on Reading-Writing Skills of the Students Who have Problems about Reading and Writing. Journal of Instructional Technologies \& Teacher Education, 7(2), 75-90. Retrieved from https://dergipark.org.tr/en/download/article-file/614063

Urhan, S., Yüksel, N. S., \& Kocadere, S. A. (2017). The evaluation of technology-based course materials developed by mathematics teachers. New Trends and Issues Proceedings on Humanities and Social Sciences . [Online], 4(9), 56-65. Retrieved from https://un-pub.eu/ojs/index.php/pntsbs/article/view/3042/3217

Van Aert, R. C., Wicherts, J. M., \& van Assen, M. A. (2019). Publication bias examined in meta-analyses from psychology and medicine: A meta-meta-analysis. PLOS ONE, 14(4), e0215052. Retrieved from https://doi.org/10.1371/journal.pone.0215052

Vincent, S. K., \& Torres, R. M. (2015). Multicultural Competence: A Case Study of Teachers and their Student Perceptions. Journal of Agricultural Education, 56(2), 64-75. Retrieved from https://files.eric.ed.gov/fulltext/EJ1122957.pdf

Wilson, M. L., Ritzhaupt, A. D., \& Cheng, L. (2020). The impact of teacher education courses for technology integration on pre-service teacher knowledge: A meta-analysis study. Computers \& Education, 156(2020), 103941. Retrieved from https://www.sciencedirect.com/science/article/pii/S0360131520301391

*Yıldız, S. (2010). The Effectiveness of Multimedia Applications in Literacy Teaching on Reading Skills. Abant Izzet Baysal University Journal of Social Sciences, 10(20) 31-63. Retrieved from https://dergipark.org.tr/en/download/article-file/154640.

Yüzlü, M. Y., \& Atay, D. (2020). The effectiveness of L1 use in promoting oral production in L2 across different proficiency levels. Journal of Language and Linguistic Studies, 16(2), 864-882. Retrieved from https://dergipark.org.tr/tr/download/article-file/1173601 